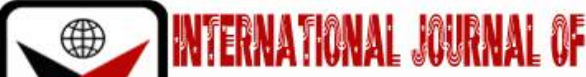

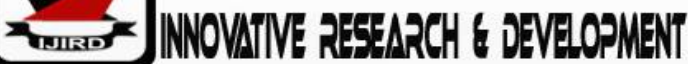

ISSN 2278 - 0211 (Online)

\section{Evaluation of the Type of Flood in Awka South Local Government Area, Nigeria}

\begin{tabular}{c} 
Anyanechi C-N. I. \\
Senior Lecturer, Department of Building Technology, \\
Federal Polytechnic Oko, Anambra State, Nigeria \\
Okolie K. C. \\
Professor, Department of Building, \\
Nnamdi Azikiwe University Awka, Anambra State, Nigeria \\
\hline
\end{tabular}

\begin{abstract}
:
This study was carried out to find out the type of flood that occurs in Awka South Local Government Area of Anambra Sate. 100 questionnaires were distributed while 83 were returned. Data collected were analyzed using descriptive statistics and mean score. The type of flood in Awka South was found out to be surface flood occasioned mainly by blocked drainages, building on water ways, inadequate or absence of drainages where necessary and heavy persistent down pour. Recommendations were made which includes discourage building on water ways, opening of blocked drainages amongst others.
\end{abstract}

Keywords: Evaluation, Flood, Awka South LGA

\section{Background to the Study}

Flood in figurative terms can be said to be a large number or quantity of anything appearing more rapidly than can easily be dealt with. It can also be defined as a (usually disastrous) overflow of water from a lake or other body of water due to excessive rainfall or other input of water (Livio, 2013).

Flood is usually disastrous overflow of water from a lake or other body of water due to excessive rainfall or other input of water. Flood can also be stated as an over flowing or eruption of a great body of water over land not usually submerged. Olajuyigbe (2012) described flooding as a large amount of water covering an area that was usually dry. According to Nwafor (2000), flood is a natural hazard like draught and desertification which occurs as an extreme hydrological event. Flood can simply be said to be a flow of water above the carrying capacity of a channel Emmanuel et al (2015). The term flood according to Jha et al. (2011) encompasses a flow of water over areas which are habitually dry.

Flooding which is the occurrence of a flood event is one of the most occurring natural disasters in the world today and could be said to have top the list of natural disasters that is becoming more of a threat than a constant or declining one (Schramn \& Dries, 1986). Alternatively, flooding can be seen as any abnormally high stream-flow that overtops the natural or artificial bank of a stream. Simply put Flood is too much water in a wrong place; whether it be inundated city or a single street or a filled flooded due to a block drain.

It covers a range of types of events, many of which can also include other sources of damage such as wind. Flooding can also occur as a result of failure of watercourses or man-made water containment systems such as dams, reservoirs and pumping systems.

In 2012, Nigeria experienced its worst floods in decades. The 2012 Nigerian flood began early July 2012, killing 365 people and displaced over 2.5million people as of November, 2012. According to the National Emergency Management Agency [NEMA] (2012), 30 of Nigeria's 36 states were affected by the flood. The flood was termed the worst in 40 years. It affected an estimated total of seven million people. The estimated damages and losses caused by the flood were worth 2.6 Trillion Naira. Over 20,000 buildings affected (NEMA, 2015).

In 2012, Anambra state was also hit by the devastating flood. It affected 57 communities in 8 local government areas, damaging 117,148 Farms and agro-based industries, 79 water and sanitary facilities, 325 schools, 122 health facilities and about 20,000 houses and damages totally about 30 billion naira (Emmanuel, Ojinnaka, Baywood, \& Gift, 2012).

In view of the effect of flood in Anambra state in 2012 in which 0ver 20,000 building, homes, schools, industries etc., were affected and what happens every year, it becomes necessary to study the type of flood in Awka which is one of the persistent places that flooding occur every year, with a view to understanding how to handle it. 


\section{Statement of the Problem}

Nigeria cannot easily forget her experiences in the famous 2012 flooding. Persistent torrential rainfall and the compelling release of water from Lagdo Dam from Cameroun, Kainji and Jebba dams in Nigeria led to massive flooding in Nigeria (Ebonugwo, Njoku, Nnabugwu, Duru \& Olasupo, 2015). These 2012 Nigerian floods killed 365 people and displaced over 2.1million people as at $5^{\text {th }}$ November 2012. According to the National Emergency Management Agency (NEMA) in Nigeria, 30 of Nigerian 36 states were affected by the floods. The floods were termed as worst in 40 years (Integrated Regional Information Network [IRIN] Africa, 2015). It affected an estimated total of seven million people (The Guardian, 2015). 45,253 buildings in Adamawa State were affected seven local government areas were lost in Benue State as reported by Ebonugwo, Njoku, Nnabugwu, Duru \& Olasupo. (2015, p.58).

Also, in Anambra State, the 2012 Flood affected 8 out of 21 local government areas of the state. Over 20,000 buildings, schools, industries and structures were affected (Emmanuel, Ojinnaka, Baywood, \& Gift, 2012). Since then flood have been devastating buildings yearly in flood prone areas of the state. The local governments areas affected includes Awka South LGA, Onitsha south, Onitsha North, Ogbaru, Oyi, Anambra East, Anambra west, and Aghamelum local governments areas.

In Nigeria, no fewer than 53 people died in 11 states from flood and displaced more than 100,420 people as at September 22, 2015. Thousands of houses, farmlands and property worth billions of Naira were all lost to the flood disaster in many local government areas affected in the northern states. The affected states are; Kano, Katsina, Sokoto, Yobe, Gombe and Bauchi and submerging a number of buildings, according to the News Agency of Nigeria [NAN], (2015). In view of the effect of flood in Anambra state in 2012 in which 0ver 20,000 building, homes, schools, industries etc., were affected and what is happening every year particularly as it affects Awka metropolis it became necessary to study the types of flood that occur in Awka Local Government Area with a view to finding solutions to them and understanding better, how to deal with its effects.

\section{Literature Review}

\subsection{Types of Flood}

Flood is of different types and there are three major ones as described by Realclimate.org (2014).

\subsubsection{Coastal (Surge Flood)}

A coastal flood, as the name suggests, occurs in areas that lie on the coast of a sea, ocean, or other large body of open water. It is typically the result of extreme tidal conditions caused by severe weather. Storm surge - produced when high winds from hurricanes and other storms push water onshore - is the leading cause of coastal flooding and often the greatest threat associated with a tropical storm. In this type of flood, water overwhelms low-lying land and often causes devastating loss of life and property.

Coastal flooding is categorized in three levels:

- Minor: A slight amount of beach erosion will occur but no major damage is expected.

- Moderate: A fair amount of beach erosion will occur as well as damage to some homes and businesses.

- Major: Serious threat to life and property. Large-scale beach erosion will occur, numerous roads will be flooded, and many structures will be damaged. Citizens should review safety precautions and prepare to evacuate if necessary.

- $\quad$ Coastal flooding caused by Hurricane Sandy ravaged the Jersey Shore in October 2012.

- The severity of a coastal flood is determined by several factors, including the strength, size, speed, and direction of the storm. The onshore and offshore topography also plays an important role. To determine the probability and magnitude of a storm surge, coastal flood models consider this information in addition to data from historical storms that have affected the area, as well as the density of nearby development.

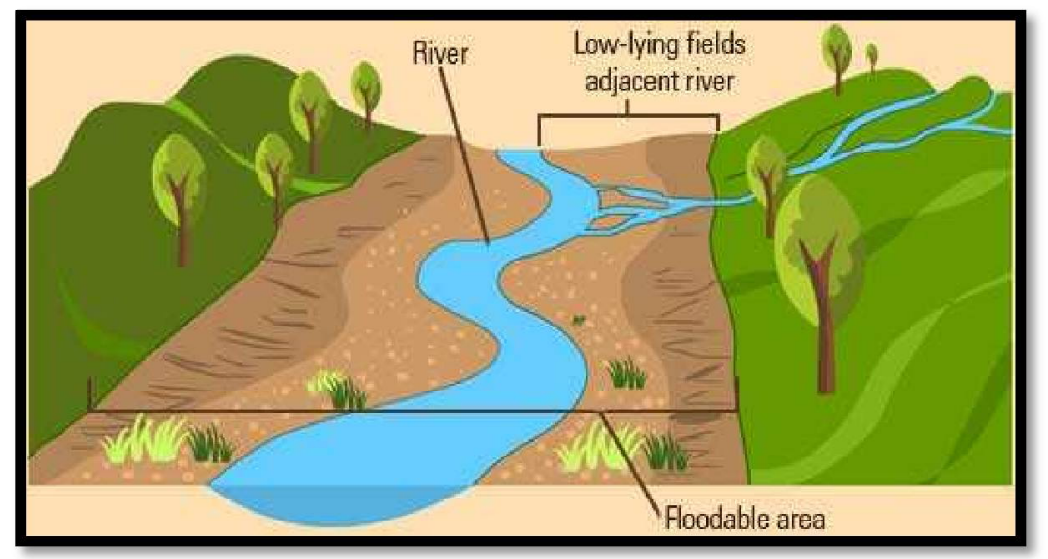

Figure 1: Coastal (Surge Flood)

Source: Realclimate.Org 


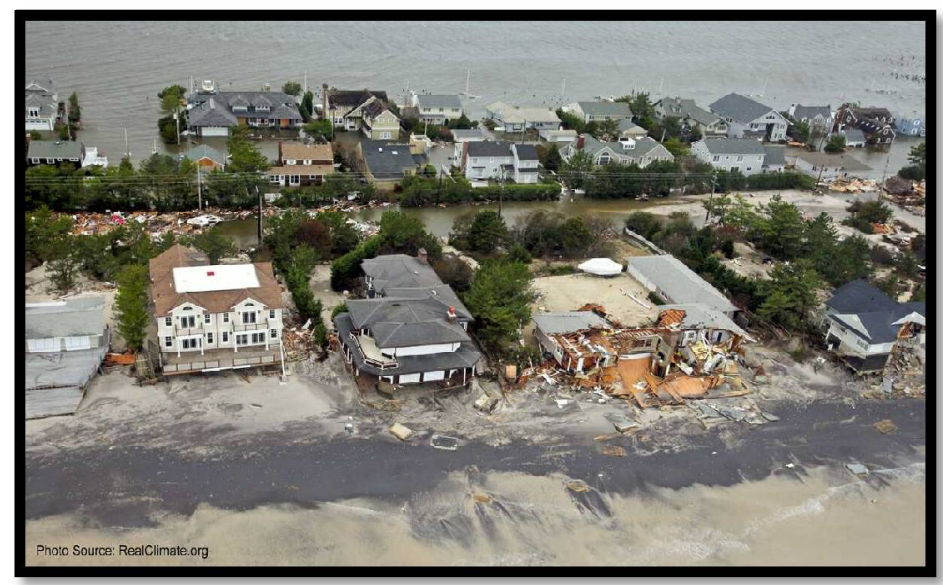

Figure 2: Coastal Flooding Caused by Hurricane Sandy Ravaged the Jersey Shore in October 2012

Source: Realclimate.Org

\subsubsection{Fluvial (River Flood)}

Fluvial, or riverine flooding, occurs when excessive rainfall over an extended period of time causes a river to exceed its capacity. It can also be caused by heavy snow melt and ice jams. The damage from a river flood can be widespread as the overflow affects smaller rivers downstream, often causing dams and dikes to break and swamp nearby areas.

There are two main types of riverine flooding:

Overbank flooding occurs when water rises overflows over the edges of a river or stream. This is the most common and can occur in any size channel - from small streams to huge rivers.

Flash flooding is characterized by an intense, high velocity torrent of water that occurs in an existing river channel with little to no notice. Flash floods are very dangerous and destructive not only because of the force of the water, but also the hurtling debris that is often swept up in the flow.

The severity of a river flood is determined by the amount of precipitation in an area, how long it takes for precipitation to accumulate, previous saturation of local soils, and the terrain surrounding the river system. In flatter areas, floodwater tends to rise more slowly and be shallower, and it often remains for days. In hilly or mountainous areas, floods can occur within minutes after a heavy rain. To determine the probability of river flooding, models consider past precipitation, forecasted precipitation, current river levels, and temperatures.

\subsubsection{Pluvial (Surface Flood)}

A pluvial, or surface water flood, is caused when heavy rainfall creates a flood event independent of an overflowing water body. One of the most common misconceptions about flood risk is that one must be located near a body of water to be at risk. Pluvial flooding debunks that myth, as it can happen in any urban area even higher elevation areas that lie above coastal and river floodplains.

There are two common types of pluvial flooding:

Intense rain saturates an urban drainage system. The system becomes overwhelmed and water flows out into streets and nearby structures.

Run-off or flowing water from rain falling on hillsides that are unable to absorb the water. Hillsides with recent forest fires are notorious sources of pluvial floods, as are suburban communities on hillsides.

\section{Research Methodology}

This research work employed exploratory research method by reviewing extensively related literature to ascertain the types of flood that occurs. Questionnaires were designed to obtain relevant information from local residents of the study area, Population, Sample and Sampling Technique. The National Population Commission (2013) gave Awka South L.G.A population as 218,156 .

This research adopted the Glenn method of published table (see table one). From the published table (see table 1), the sample size for a population of more than 100,000 at $5 \%$ precision level is 400 (Glenn, 2013). This number was reduced to 100 and concentrating in some sections of the local governments and not the entire local governments. 


\begin{tabular}{|c|c|c|}
\hline Size of Population & $\begin{array}{c}\text { Sample Size (n) for precision (e) } \\
\mathbf{+} \mathbf{5 \%}\end{array}$ & $\begin{array}{c}\text { Sample Size (n) for precision (e) } \\
\mathbf{+} \mathbf{1 0 \%}\end{array}$ \\
\hline 500 & 222 & 83 \\
\hline 1,000 & 286 & 91 \\
\hline 2,000 & 333 & 95 \\
\hline 3,000 & 353 & 97 \\
\hline 4,000 & 364 & 98 \\
\hline 5,000 & 370 & 99 \\
\hline 7,000 & 378 & 99 \\
\hline 9,000 & 383 & 99 \\
\hline 10,000 & 385 & 99 \\
\hline 15,000 & 390 & 100 \\
\hline 20,000 & 392 & 100 \\
\hline 25,000 & 394 & 100 \\
\hline 50,000 & 397 & 100 \\
\hline 100,000 & 398 & 100 \\
\hline 100,000 & 400 & \\
\hline
\end{tabular}

Table 1: Sample Size for + _5\% and $+\ldots 10 \%$ Precision Levels

Where Confidence Level is $95 \%$ and $P=0$.

Source: Sigh \& Masuku, (2014) adopted from Glenn, (1992)

From table 1 the population of study is 400 but due to logistic reasons, the population of study was further reduced to 100 and the searcher concentrated on the parts of the Local Government area that witnesses flood events. Questioner was designed and administered to the inhabitants of the area. Descriptive statistics and mean score were used in the analysis of the data. Out of 100 questionnaires distributed 83 were completed and returned representing $83 \%$.

\subsection{Method of Data Analysis}

Descriptive statistic and mean score were used.

\section{Result}

\subsection{Respondents Response on the Type of Flooding They Have Witnessed in Awka South}

\begin{tabular}{|c|c|c|c|c|c|c|c|c|c|}
\hline S/N & Factors & $\begin{array}{c}\text { Strongly } \\
\text { Agree }\end{array}$ & Agree & Undecided & Disagree & $\begin{array}{c}\text { Strongly } \\
\text { Disagree }\end{array}$ & $\begin{array}{l}\text { Mean } \\
\text { score }\end{array}$ & Ranking & Remark \\
\cline { 2 - 7 } & $(5)$ & $(4)$ & $(3)$ & $(2)$ & $(1)$ & & \\
\hline $\mathbf{1}$ & $\begin{array}{c}\text { Coastal (Surge } \\
\text { flood) }\end{array}$ & 0 & 0 & 2 & 20 & 58 & 1.30 & 3 & Disagree \\
\hline $\mathbf{2}$ & $\begin{array}{c}\text { Fluvial (river } \\
\text { flood) }\end{array}$ & 1 & 1 & 4 & 10 & 64 & 1.31 & 2 & Disagree \\
\hline $\mathbf{3}$ & $\begin{array}{c}\text { Pluvial (Surface } \\
\text { flood) }\end{array}$ & 64 & 12 & 2 & 1 & 1 & 4.71 & 1 & Agree \\
\hline
\end{tabular}

Table 2: Respondents' Response on the Type of Flooding They Have Witnessed in Awka South

Source: Anyanechi, (2019)

\subsection{Decision Rule}

In the ranking of the responses of the respondents, the responses with mean value of 3.0 and above was regarded as agree, while mean values that fall below 3.0 was regarded as disagree. The respondents' responses to the question were presented and analyzed in tables 2 .

The result showed that Pluvial (surface flood) is the type of flood in Awka South LGA. With mean score of 4.71. While Coastal flood and Fluvial flood with mean scores of 1.3 and 1.31 respectively were rejected.

\section{Conclusion}

It is concluded that the type of flood in Awka North is predominately surface flood caused by mainly blocked drainages, inadequate or non-availability of drainages heavy and persistent down pour and building on water ways.

\section{Recommendation}

- People should be discouraged from building on flood channels in Awka South Local Government Area.

- Blocked drainages should be opened for easy flow of flood waters during heavy down pour. Also, where drainages are found to be inadequate better and bigger drainage should be provided to contain flood water. And where absence of drainage is causing flooding one should be provided.

- Rapid urbanization and urban expansion should be controlled as people build indiscriminately without control and planning 


\section{References}

i. Anyanechi C-N. I. (2019) Development of a quality management frame work for the construction of flood resilient buildings in Anambra State Nigeria. An unpublished PhD dissertation Nnamdi Azikiwe University Awka, Anambra State Nigeria.

ii. Ebonugwo M., Njoku J., Nnabugwu F, Duru P., \& Olasupo F. Flood disaster. (2015). looms, features Vanguard Newspaper September 9, 2015. p.58.

iii. English Dictionary 1.2.2. (2013). (Liviojavalcb@gtmail.com) extracted from http://wikionary.org. Accessed 24-0915.

iv. Emmanuel U. A., Ojinnaka O.C., Baywood C.N., \& Gift U.A. (2012). Flood Hazard Analyses and Damage Assessment of 2012 Flood in Anambra State Sing GIS and Remote Sensing Approach. American Journal of Geographic Information System 2015, 4(1): 38-51. DOI. 10.5923/j.ajgis.2015041.03.

v. Integrated Regional Information Network (IRIN) AFRICA. (2012). "NIGERIA Worst flooding in decades". IRIN Africa. October 10, 2012 retrieved May 27th 2015.

vi. News Agency of Nigeria (NAN). (2015). National Tragedy: Floods kill 53, displaced 100,420 people across Nigeria. Premium Times Friday, September 25, 2015, posted 20 September at www.prenumtime.com. Accessed September 25th, 2015.

vii. Nigerian Bureau of Statistics. [NBS]. (2015). Nigerian Real Estate Sector. Summary report 2010 - 2012. Assed from www.nigerianbureauofsatistics.org.ng on $5^{\text {th }}$ of March 2017

viii. National Emergency Management Agency, (NEMA). (2015). "2012 flood disaster cost Nigeria \#2.6trn-NEMA punching.com. Retrieved May 27th, 2015. Accessed in wikipedia.com.

ix. Nwafor, A. N. (2014). Flood extent mapping in Bayelsa state, Nigerian journal of Geography, vol. 8(33), pp. 18-29.

x. Olajuyigbe E.A. (2012). Mapping and Analysis of 2012 flood Disaster in Edo State Using Geospatial technic. Journal of Environmental Sciences, vol. 6(5), p. 32-44

xi. Singh A. S. and Masuku M. B., (2014). Sampling Technique and Determination in Applied Statistics Research: An Overview. International Journal of Economics, Commerce and Management Vol. 11, Issue11 Nov. 2014. (21131) pdf

xii. The Guardian Newspaper, (2015). "Nigeria floods test government's disaster plans" The Guardian in Wikipedia. Retrieved May 27th 2015. Accessed August 20th 2015.realclimate.org

xiii. Real Climate (2014) Climate Science from climate scientists. Realclimate.org. Accessed $4^{\text {th }}$ April 2014 